\title{
岩手県金石鉱山新山鉱床の磁気学的研究 (II)
}

Studies on the magnetic properties of the Shinyama ore body of Kamaishi iron and copper ore deposits, Iwate Prefectune (II)

上野宏共 (Hirotomo Ueno)

\section{6. 帯碰本}

\section{1 測定器具および方法}

第 11 区心装置を組み弹動恰流計法で行つた。㸮末にした試料を急速に 2 次コイル内 にそう入したときの磁束变化を2次コイルに生ずる電気量の变化に変えて弾動検流計で 読みとる方法である。コイルは地球磁場の方向と垂直に置くので測定磁場の強さは 1 次 コイルに流す電流で自由に妾えられる。

弾動娭流計の振れ $\theta$ は次の式で示される。

$\theta=C \cdot s \cdot k \cdot h$

$\kappa ;$
$h ; 1$

(测定磁場)

$s$; 試料の断面積

$C$; 測定回路の定数

この式加ら需磁率火が計算で きる。但し，用いる試料は粉末 であるから，測定結果は带磁率火 を試料の装填比重で除した比带 磁躍入として示す。

\section{2 測定結果および考察}

測定結果およひ凰連した計算

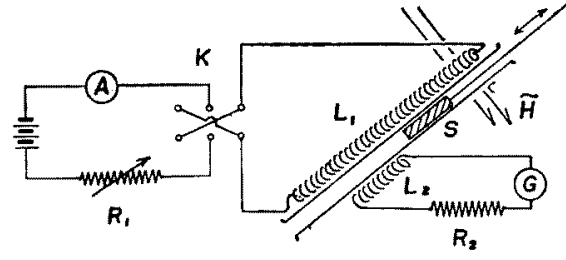

第11 図 带磁率湘定装置

$G$ : 弾動検流計 $S$; 試料

$A$; 電流計 $\tilde{H}$; 地球磁場

$L_{1} ; 1$ 次コイル $L_{2} ; 2$ 次コイル

$R_{1}$ ；スライド抵抗器 $R_{2}$; 外部臨界抵抗

$K$; 測定磁場の極性スイッチ

値を第 3 表に示す。

測定磁場は地球磁場の全磁力にあたる 0.45 Oe 位にして測定ず゙きであるが測定装置 の感度が低いため $5.5 \mathrm{Oe} の$ 磁場で測定した。比較上, 磁鉄鉱含有の試料のみ $1.0 \mathrm{Oe}$ の磁場での測定值を示したが，類似した值を示している。

地球磁場の中に置かれた岩石や鉝石の磁化の强さ $I$ は次のように示される。

$$
\begin{array}{ll}
I=I_{r}+I_{i} & I_{r} ; \text {; 残留磁気の強さ } \\
=I_{r}+\kappa H & I_{i} ; \text { 誘導磁気の強さ } \\
& \kappa ; \text {; 芇磁率 } \\
& H \text {; 地球磁場の全磁力 }
\end{array}
$$

即ち, 残留磁気と地球磁場による諉毞磁気の両者が関与している。 
第3表 带磁密㧍よび誘導磁気

\begin{tabular}{|c|c|c|c|c|c|c|c|c|c|}
\hline $\begin{array}{l}\text { 謴定磁 } \\
\text { 䔾( } \\
h(\mathrm{Oe})\end{array}$ & | & 試 & 棌 & 置 & & 场 & $\mid \begin{array}{c}\mid \text { 比兴磁率 } \\
\chi \\
\times 10^{-3} \\
\end{array}$ & 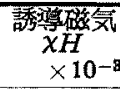 & \\
\hline 5.5 & $\begin{array}{l}2201 \\
2213 \\
2403 \\
0802\end{array}$ & $\begin{array}{c}\text { No. } 2 \\
" \prime \\
\prime \prime \\
\text { No.4 }\end{array}$ & $\begin{array}{l}\mathrm{S} 300 \\
\prime \prime \\
\mathrm{N} \quad 60\end{array}$ & $\begin{array}{lc}500 \mathrm{M} & 5 \varepsilon^{-} \\
500 \mathrm{M} & 2 \mathbf{E} \\
450 \mathrm{M} & 1 \mathbf{E}^{\mathbf{2}} \\
450 \mathrm{M} & \mathrm{L}\end{array}$ & $\begin{array}{l}\mathrm{Di} \\
\mathrm{Di} \\
\mathrm{Di} \\
\mathrm{Cp}\end{array}$ & $\begin{array}{lll}\text { Cp } & \text { Po } & \text { Cal } \\
\text { Cp } & \text { Po } \\
\text { Po } & \text { Cp } \\
\text { po } & \text { Cal }\end{array}$ & & & $\begin{array}{l}1 . \\
1 . \\
0 . \\
0 .\end{array}$ \\
\hline & \begin{tabular}{|}
2907 \\
2913 \\
2315
\end{tabular} & $\mathrm{Cu}$ & $\begin{array}{l}\mathrm{N} \quad 60 \\
\mathrm{~S} \quad 300\end{array}$ & $\begin{array}{cc}450 \mathrm{M} & \mathrm{L} \\
{ }^{\prime \prime} & \stackrel{\prime \prime}{ } \\
450 \mathrm{M} & 3 \mathrm{E}^{-}\end{array}$ & $\begin{array}{l}\text { Mt } \\
\text { Mt } \\
\text { Gt }\end{array}$ & Mt & $\begin{array}{l}9 \\
1\end{array}$ & & $\begin{array}{l}0 . \\
0 . \\
0 .\end{array}$ \\
\hline 1.0 & 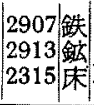 & $\begin{array}{c}\mathrm{Fe} \\
\mathrm{Fe}^{\prime \prime} \mathrm{Cu}\end{array}$ & $\begin{array}{l}N \quad 60 \\
S \quad 300\end{array}$ & $\begin{array}{cc}450 \mathrm{M} & \mathrm{L} \\
" \prime & \prime \prime \\
450 \mathrm{M} & 3 \mathrm{E}^{-}\end{array}$ & $\begin{array}{l}\mathrm{Mt} \\
\mathrm{M} t \\
\mathrm{G} t\end{array}$ & $\begin{array}{l}\mathrm{Gt} \\
\mathrm{Mt}\end{array}$ & $\begin{array}{l}90.4 \\
11.0\end{array}$ & & 0.1 \\
\hline
\end{tabular}

強磁性鉣物の種類や含有量によつて比带磁弶の值が買なるのは当然であるが，第 3 表 に示したように鉄鉱床と銅鉱床とでは大きな差がある。 $\chi H$ の值で比較すると

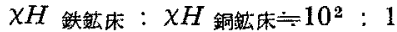

である。即ち，地球磁場による誘導磁気では鉄鉣床は銅鉣床の約 100 倍である。

次に，残留磁気と誘導磁気の比 $Q$ をとれば第 3 表に示したようである。銅鉣床では差 はあるが，ほぼ same order で，鉄鉱床では牫留磁気より誘導磁気の方が大きく作用し ている。

\section{7. 磁化满 の考察}

残留磁気の方向および带磁率の值を基にして磁化機椣を考えてみる。

\section{$7 \cdot 1$ 残留磁気の方向の総括}

これまで述へた残留磁気のうち測定個数が多く，鉱体全体の值として弅理てきるのは鉄 鉣床，第 2 銅鉣床.S 300 附近，第 4 銅銥床の 3 鉱体である。

鉄鉱休はNo. 2911 を除いいた 17 個で，第 4 銅鉣床は赤鉄鉱*を含まない第 5 銅鉱 休の 2 個を加えて，測定可能なもの 17 個でそれぞれの鉱体を代表させる。第 2 銅鉣で

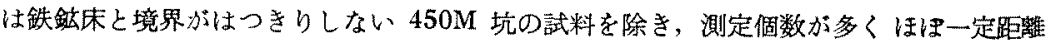
で鉄鉣床に近接する「S 300 垂值方向と S 300 附近」の測定可能な 23 個で第 2 銅鉱床 を代表させる。

これらをシュミットホットに投影して集中域を求めたのが第 12 図〜第 14 図である。

\section{2 鉄鉱床}

強磁性体の磁化機㩐は䍜雑であるが一般的に次のように䓂える。磁束線は透磁率を異 にする物望の境界面で屈折する。磁束線が境界面の法線となす角を $\theta_{1}, \theta_{2}$ とすれば

$$
\frac{\tan \theta_{1}}{\tan \theta_{2}}=\frac{\mu_{1}}{\mu_{2}}
$$

となる。鉄鉱床の透磁率 $\mu_{1}$ は鉄鉣床の外部の透磁率 $\mu_{2}$ より大きいから**磁柬線が 鉄 欲床内に入るときは内部では境界面とは小さな角度をなして進む(Kuzhelov，1957)。

* 赤鉄鉣の寄生强磁性鉣物としての検討をなさなかつたので除外した。

** 単位系は C.G.S. 電磁単位系に統一した。 $\mu=1+4 \pi \kappa$ から明らかである。 

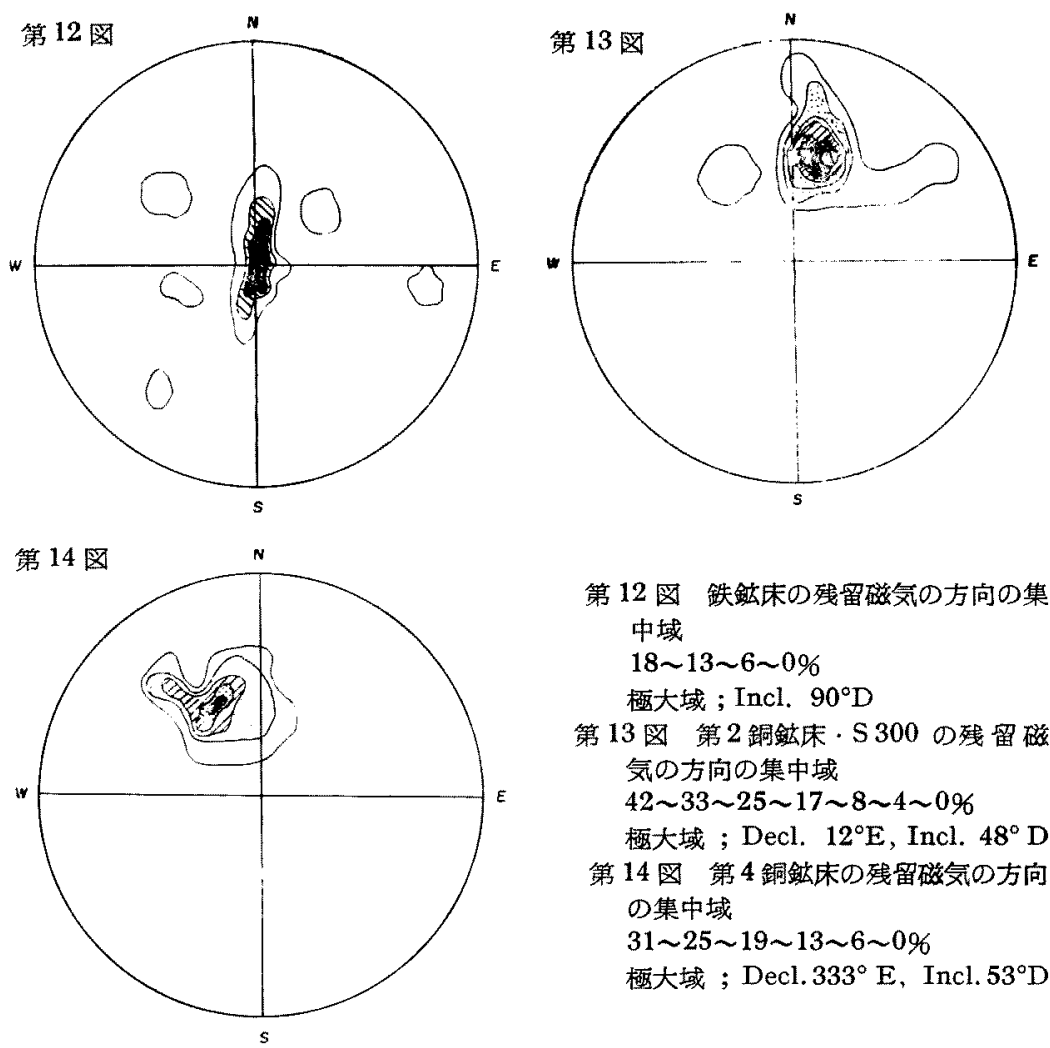

第 12 図 鉄鉣床の残留磁気の力向の集 中域

18〜13 6 6 0\%

極大域 ; Incl. $90^{\circ} \mathrm{D}$

第 13 図 第 2 銅鉝床. S 300 の残留磁 気の方向の集中域 42 33 25 17 8 8 4 096

極大域 ; Decl. $12^{\circ} \mathrm{E}$, Incl. $48^{\circ} \mathrm{D}$

第 14 図 第 4 銅鉣床の残留磁気の方向 の集中域

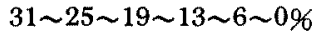

極大域 ; Decl. $333^{\circ} \mathrm{E}$, Incl. $53^{\circ} \mathrm{D}$

棈円体の磁化は詳しく計算されている（竹山，1944）。棈円体の方程式を

$$
\frac{x^{2}}{a^{2}}+\frac{y^{2}}{b^{2}}+\frac{z^{2}}{c^{2}}=1
$$

とする。棈円体内の透磁率を $\mu_{1}$, 桂円体外の透磁率を $\mu_{2}$, 外部加ら加える均等磁場を $H_{0}$ 之すれ洼，棈円体内に於汀る磁場 $\boldsymbol{H}_{i}$ の三成分は

$$
H_{i x}=\frac{H_{0 x}}{1+\frac{\mu_{1}-\mu_{2}}{\mu_{2}} A}, H_{i y}=\frac{H_{0 y}}{1+\frac{\mu_{1}-\mu_{2}}{\mu_{2}} B}, H_{i z}=\frac{H_{0 z}}{1+\frac{u_{1}-\mu_{2}}{\mu_{2}} C}
$$

である。こっでは $\mu_{2}=1$ としてよいから

$$
\frac{H_{i x}}{H_{i z}}=\frac{1+\left(\mu_{1}-1\right) C}{1+\left(\mu_{1}-1\right) A} \cdot \frac{H_{0 x}}{H_{0 z}}=\frac{1+4 \pi \kappa C}{1+4 \pi \kappa A} \cdot \frac{H_{0 x}}{H_{0 z}}
$$

$A, B, C$ は棈円積分で示される式であつて $c>a$ ときは, $A>C$ である。 銅鉝床の項で触れるが $\frac{H_{\mathbf{0 x}}}{H_{\mathbf{a} z}}<1$ であるから

$$
\frac{H_{i x}}{H_{i z}}<1
$$


となる。榃円体の長軸方向の磁場が傮越する。

反磁埸の锶点吕ら考えて，各方向の反磁場係数を $\nu_{a}, \nu_{b}, \nu_{c}$ とすると

$$
v_{a}=4 \pi A, \quad y_{b}=4 \pi B, \quad y_{c}=4 \pi C
$$

である。長軸方向の区磁場係数は小さくなる。

もつとも極端な場合をとつて回耺棈円体 $a=b \ll c$ として

$$
\nu_{a}=\nu_{b}=2 \pi \quad \nu_{c}=0
$$

となることからも分る。

即ち，均等磁場の中に置かれた磁性棈円体は，その長軸方向に磁化されやすい。

鉄鉣床生成とその磁化に関して考祭する。最初，地球の磁埸内で磁鉄鈗の小さい核が 生成される。この核は super paramagnetism (Bean, 1955) の現象を示すから粒子の 磁気モーメントの熱振勤エネルギーが主な役㓶を演じ抗磁力は小さい。従つて地球の磁 場の方向に磁化される。次の段階では粒子の成長が進み体皘が大きくなると緩和時間 (Néel，1949）が急に大となり高い抗磁力を示す安定しだ磁化が固着される。ここまでの 段階では単磁区梏浩である。さらに結晶成長が進むと磁壁が現われて，いくつかの磁区に 分れる。現象面では高温から泠却された物質が その時の磁場の力向を容易磁化軸として 自発磁化の问きが安定するような単軸磁気異方性を生する磁界中椧却効果 (Néel，1954； Chikazumi and Oomura，1955) が筧されている。及，磁場中でパーマロイなどの合 金を藻着するとき，その磁場方向に容易磁化軸を生して著しい単軸磁気異方性が現われ


ここでもこれらと同様学効果が現われ，磁化の際の磁場位存性が現われると推定される。 このときには既に磁鉄鉣は磁性体としての働きをなしているから檍円体の磁化機構で 述へたように鉣体の伸びの方向の磁場が優越し，磁化はこの方にそろつてくる。その 上，磁鉄鉱だけとりあげても各結晶の晶出には range がある。後から生ずる磁鉄鉣は先 に晶出した磁鉄鎕に基ずぐ鉣体の伸びの方向に優越する磁場、によつて影響を受ける。 磁気エネルギーが最小になるように磁区が配列するから磁化の総和は個久の結晶の成長 が進むにつれて減少する。

一方，磁鉄鉱自体の異方性定数は

$$
K_{1}=-1.35 \times 10^{-4} \mathrm{erg} / \mathrm{cc}
$$

である。 $K_{1}<0$ の場合には [111]，[111]，[111]，[111]の4方向が磁気エネルギー極小 上なり磁化容易方向である。鉄銃床磁化の際の各結晶の磁化方向の“ばらつき:はある であろう。これ以外に夾雑物としての珪酸塩鉣物の影響や磁鉄鉱の形・大きさ・分布の

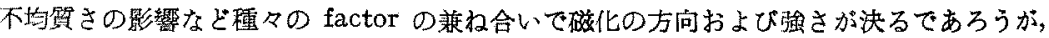
全体としては鉿体の伸びの方向に磁化されると推定される。

このようにして結晶成長中に固着した磁区をその後㚆化させるには大きい磁気エネル ギーを必要とする。


鉱床の上部は現在，崩落しているが 生成当時の上下方向の伸びはかなりあつたと考えら れる。

以上考察した磁化機槽から鉄鉱床は生成の際，鉱体の伸びの力向に带磁し，集中域の NS の振れは鉄鉱床の NS 方向の伸びによるのと説明することができる。 


\section{$7 \cdot 3$ 銅鉱床}



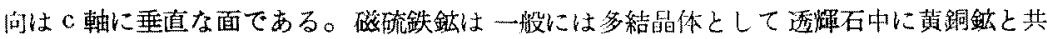
生する。鉄鉣床の磁鉄鉣が䂝留磁谷を㺘得するのと同椂に， super paramagnetism $\rightarrow$ 固

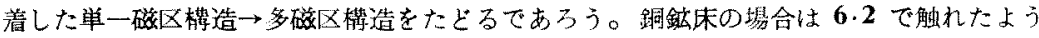
に誘導磁気に上る影贸が少なく鉣体の形にかいわらずに外部磁場の方向に磁化する。但 し，銅鉱床の生成時には鉄銥床が存在しているので地球磁場と鉄鉱床自体による磁束線 を合成した外部䂭境を考える必要がある。

[铁鉣床に上る磁気巽常]



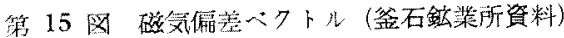

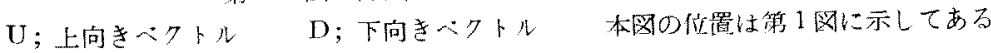

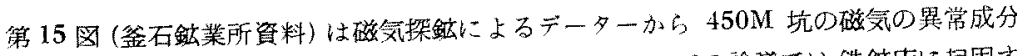

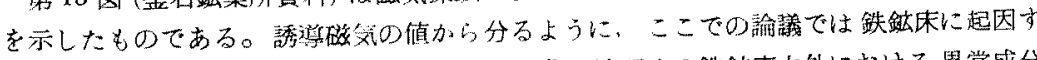
る偏差として扱つて差しつかえない。採掘の進んた現在の鉄鉣床内外にお忛る翼常成分 であるから廠泌には銅鉱床生成当時よりその值はいく分小さくなつているであるうが近 似する。鉄鉣床の内部では磁気偏差ベクトルは下向きであるが第2 銅鉱床・S 300 附近て は上向きで に振れている。

図は省略したが 500M 坑のS300 附䜣では罢裳成分はいく分大きいが同じ傾向を示し ている。

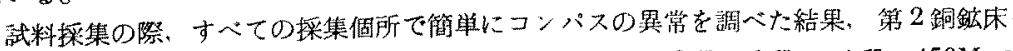
S 300 附近では 550M 坑，500M の5段・4段・3段・2段・1段・中段，450M の 
4 段・ 3 段・ 2 段・1段でも類似した偏差を示している。

\section{[第 4 銅銃床]}

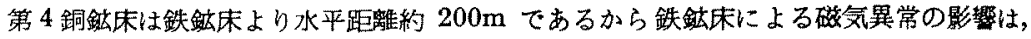
鉄鉝床に近接する第 2 銅銥床のそれと比較すれば，ここで报う問題では無視して差しつ かえない程度である。このことは坑内磁力探鉉のデーターや坑内各個所でのコンパスの 異常加的鳋付けられる。

第 4 銅鉱床は鉱床生成の際，地球磁場上類似した方向に磁化したと推定される。

北上山地のジラ紀・白严紀の岩石磁気のデーター(Nagata and others, 1961) や北 上山地の棈造発達史 (小貫, 1963) 功当時の地球磁場の方向を推論する手段はあるが， 地塊化運動 (Moriai，1964)，鉱床生成後の㚆動等（小貫，1964）加ら釜石鉉山附近の值

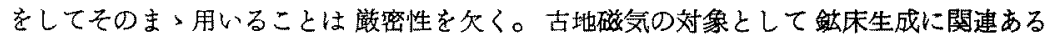
进入火成岩類が使えるなら，この测定值で 錙床生成当時の地球磁場を代表させることが できる

\section{[第 2 銅销床]}

第 2 銅鉝床 .5300 の試料の 残留磁気の 方向の集中域を第 4 銅鉙床のそれと比較する (第 13 図, 第 14 図)。

第 2 銅銥床. S 300 Decl. $12^{\circ} \mathrm{E} \quad$ Incl. $48^{\circ} \mathrm{D}$

第 4 銅鉙床 Decl. $333^{\circ} \mathrm{E} \quad$ Incl. $53^{\circ} \mathrm{D}$

第 2 銅鉣床.S 300 附近では第 4 銅鉱床より Decl. では東 (E)に $29^{\circ}$ ，Incl. では下 (D)に $5^{\circ}$ 偏つている。

水平的な取り报いるしてみる。推定される当時の地球磁場 $\boldsymbol{G}$ ，铁鉣床による偏位 $\boldsymbol{V}$ ，第 2 銅鉣床・S 300 の残留磁気の方向 $R$ を示すと第 16 図の上うである。鉣床生成当時の明 確な地球磁場の方面およひ㧧度が分らないので定量的な扱いはできないが，GとVを合 成すれば $\boldsymbol{R}$ に近いものができる。

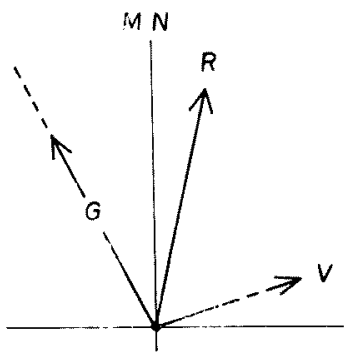

第 16 因第 2 銅鉉床の磁場

$\boldsymbol{R}$; 第 2 銅鉝床 $\cdot \mathrm{S} 300$ 附近の残留 磁気の方向

$\boldsymbol{V}$; 鉄鉱床による揙位

$G$; 地球磁場

これまで考察してきたように磁化機稗の観点からも同様に鉄鉣床生成後銅鉱床生成と
垂直的には大きな偏りはないが，第2 銅 鉣床の方が上向きである。鉄鉱床による磁 気偏位方第 2 銅鉣床の内部で上向きである 事実（第 15 园）から次のように言える。 鉄鉱床の存在による磁気異常によつて上向 きのヘクトルが加算された。

要約すると，第 2 銅鉱床は鉄鉙床自体に よる磁束線と地球磁場を合成した磁場に類 似した方向に鉱床生成の際磁化した。

新山鉝床の生成に関しては镐床学的に次 のように言われている(鶴島，1960）。白 垔紀末の造山運動と一連の動きである花崗 閅緑岩の貫入に継ぎスカルン化作用，磁鉄 鉣の晶出が行われた。この後, 硫化鉱物の 鼠出が行なわれた。 
言う鉱化作用の前後関係を説明することができる。
8.ま
$\downarrow$
$\infty$

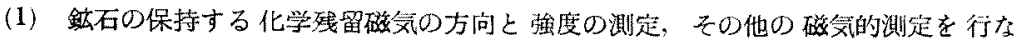
い，岩石磁気の鉱床学への応用を試みた。

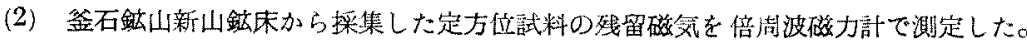

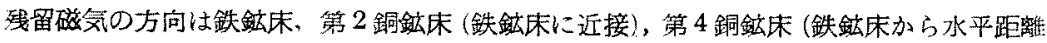
約 $200 \mathrm{~m})$ の各鉣体ごとに明らかな違いがある。

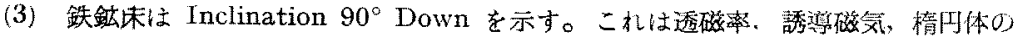
磁化機構などから鉄鉱床が鉄鉱床生当成時に鉱体の伸びの万向に磁化したためである。

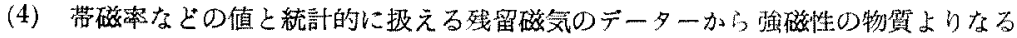
鉣体の伸びの方向を予測することも可能である。

(5) 第 2 銅鉝床は Declination $12^{\circ} \mathrm{E}$, Inclination $48^{\circ}$ Down を示す。これは鉄鉱 床に起因する䃍気異常によつて第 2 銅鉣床が 銅鉱床生成の際当時の地球磁場の方向から 偏つて磁化したためであるう。

(6) 第 4 銅鉱床は Declination $333^{\circ} \mathrm{E}$, Inclination $53^{\circ}$ Down 示す。第4 釦鉱 床は鉄鉱床の影響なあまり受けず当時の地球磁場に類似した方向に銅鉙床生成の際に磁 化したと推定される。

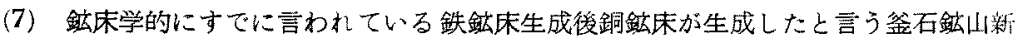
山鉣床の鉣化作用の前徯関係を全く違つた見地から説明しうる。

（8）熱磁気測定から鉄鉣床の磁性に值接関与する酸化鉱物は磁鉄鉱のみであることが 判明した。

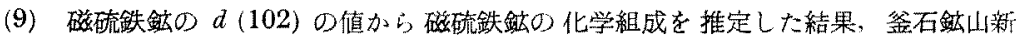
山鉱床の磁硫鉄鉣はフェリ磁性を示す成分範围のものである。

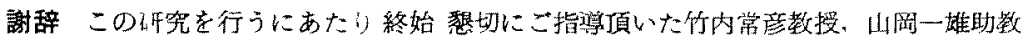
授に深く謝意を表する。種々の有益なるご示喛を頂いた東北大学理学部地球物理学教室 高木章雄助教授には心から感謝の意を表する。同教窒の室井勲氏，青山籍氏，金属材料 研究所の山内宏氏には实駼操作のみならす種々の点でこ指等頂き，試料採集にあたつて は日鉄鉱業の釜石鉱業所大多和精一所長、現・八茎鉱業所和田成人副所長、田中良雄氏

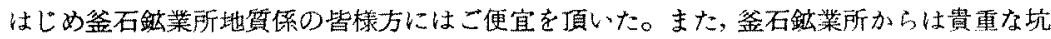
内磁力探鉉の資料を使用させて頂いだ。こいにあらためて感謝する。

\section{引用文献}

秋元伐一 (1959)，岩石の磁受， 山本物理学会誌，14，447〜 457.

Arnold, R.G. (1956), The pyrrhotite-pyrite relationship, Carnegie Inst. Wash. Year Book, 55, 177 178 .

Bean, C.P. (1955), Hysteresis loops of mixtures of ferromagnetic micropowders, Jour. Appl. Phys., 26, 1381 1383.

Blois, M.S. (1955), Preparation of thin magnetic films and their properties, 
Jour. Appl. Phys., 26, 975 980.

Chikazumi, S. and T. Oomura (1955), On the origin of magnetic anisotropy induced by magnetic annealing, Jour. Phys. Soc. Japan, 10, 842 849. 近角樒信 (1961), 强磁性体の物理，裳華房

Haigh, G. (1958), The process of magnetization by chemical change, Phil. Mag., 3, 267 286.

Haraldsen, H. (1937), Eine thermomagnetische Untersuchung der Umwandlungen im Troilit-Pyrrhotin-Gebiet des Eisen-Schwefel-Systems, Zeit. anorg. u. allg. Chem., 231, 78 96.

Kobayashi, K. (1959), Chemical remanent magnetization of ferromagnetic minerals and its application to rock magnetism, Jour. Geomag. Geoelect., 10, $99 \sim 117$.

Kobayashi, K. (1961), An experimental demonstration of the production chemical remanent magnetization with $\mathrm{Cu}-\mathrm{Co}$ alloy, Jour. Geomag. Geoelect., 12, 148 164 .

Kuzhelov, G. K. (1957), Some instances of thermomagnetization of ferromagnetic bodies, Izv. Akad. Nauk SSSR, ser. geofiz., 7, 944 949.

Moriai, T. (1964), The geology and geological structure of Kamaishi and its environs, Iwate Prefecture, Doctor thesis, Tohoku Univ.

永宮健夫・他 (1961)，物䐝の磁性，共立出版

Nagata, T. (1961), Rock magnetism, Maruzen.

Nagata, T., S. Akimoto, Y. Shimizu, K. Kobayashi, Y. Syono and H. Kuno (1961), Palaeomagnetic study on Cretaceous and Jurassic rocks in Kitakami district (abstract), Jour. Geomag. Geoelect., 12, 168.

Nicholls, G.D. (1955), The mineralogy of rock magnetism, Advanc. phys., 4, $113 \sim 189$.

Néel, L. (1949), Théorie du trainage magnétique des ferromagnétiques en grains fins avec applications aux terres cuites, Ann. de Géophys., 5,99 136.

Néel, L. (1954), Anisotrople magnétique superficielle et surstructures d'orientation, Jour. Phys. et Rad,, 15, 225 239.

小貫義男 (1963)，榯造発達史から見た北上山地の特長，地資学会 70 年総会討論会資 料

小貫男 (1964)，白垔紀の運動の特殊性，花崗岩類进入の時間的 range（談話） 大町北一郎 (1958)，公石銥山，未利用鉄資源， 5, 225 232.

Stacey, F.D. (1963), The physical theory of rock magnetism, Advanc. Phys., $12,45 \sim 133$.

竹内常彦, 南部松夫, 和田成人 (1952), 金石鉱山 産磁鉄鉱の不完全性について, 岩 鉣, 37, 75 82.

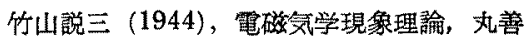




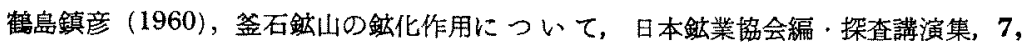
$13 \sim 19$.

Tsusue, A. (1961), Contact metasomatic iron and copper ore deposits of the Kamaishi mining district, northeastern Japan, Jour. Fac. Sci. Univ. Tokyo, sect. $2,13,133 \sim 179$.

Williams, H.J. and R.C. Sherwood (1957), Magnetic domain pacterns on thin films, Jour. Appl. phys., 28, 548 555.

山岡一雄 $(1960)$ ，キースラガー鉱床に見られる緑泥石岩中の磁鉄鉣，赤鉄鉣及びマグ ネシオフェライトについて，岩鉱，44，162〜170.

Yamaoka, K. (1962), Studies on the bedded cupriferous iron sulfide deposits occurring in the Sambagawa metamorphic zone, Sci. Rep. Tohoku Univ., ser. $3,53,1 \sim 68$. 